1349 Jurnal Idea Hukum

Vol. 5 No. 1 Maret 2019

Magister Hukum Fakultas Hukum Universitas Jenderal Soedirman

\title{
TINJAUAN YURIDIS TERHADAP KONSTRUKSI HUKUM BADAN USAHA MILIK DESA (BUMDesa) DI KABUPATEN BANYUMAS Oleh: Rizky Priambodo
}

\begin{abstract}
Village-Owned Enterprises (BUMDesa) in the legislation do not specifically explain the form of legal entity, type of company on BUMDesa, form of BUMDesa accountability with BUMDesa business units, and types of civil legal entities in BUMDesa business units.

Research entitled "Juridical Review of Legal Construction of Village-Owned Enterprises (BUMDesa) in Banyumas District" aims to analyze the legal construction of Village-Owned Enterprises (BUMDesa) and to analyze the implementation of the formation of Village-Owned Enterprises in Banyumas Regency, provide information to $B U M D e s a$ which will be formed so that there is no law violation.

The research method with normative juridical law research and research specifications is prescriptive. Data collection methods are literature studies or literature. The method of presenting data in the form of a description that is arranged systematically and the method of analysis used instudy thisis a qualitative normative analysis method.

BUMDesa is constructed that BUMDesa is a Company and Business Entity because it meets the characteristics of the company, namely, aiming to make a profit, continuously, owning an organization. BUMDesa is a public legal entity because it was formed through village regulations. BUMDesa is a public legal entity in the form of a Public Corporation because it is identical with the characteristics of a PERUM-shaped $B U M N$. BUMDesa's accountability with the BUMDesa Business Unit is a group company because BUMDesa as the holding company has an economic unit with the BUMDesa business unit and is separated juridically between BUMDesa and the BUMDesa Business Unit. BUMDesa implementation in Banyumas Regency is that the application of laws and regulations on BUMDesa in Banyumas Regency is partly implemented, namely BUMDesa is formed through legislation namely Perdes which is not divided into shares, and the establishment of a civil legal entity in the BUMDesa business unit has not been implemented in large numbers.

Conclusion, the construction of BUMDesa is in the form of a Public Legal Entity in the form of a Perumdes, with the form of accountability with the BUMDesa business unit in the form of a group company. Part of the implementation of BUMDesa in Banyumas District has been implemented in accordance with the prevailing laws and regulations. Keywords: Legal Construction, BUMDesa Banyumas Regency.
\end{abstract}

\section{Abstrak}

Badan Usaha Milik Desa (BUMDesa) dalam peraturan perundangan tidak menjelaskan secara khusus tentang bentuk badan hukum, jenis perusahaan pada BUMDesa, bentuk pertanggungjawaban BUMDesa dengan unit usaha BUMDesa, dan jenis badan hukum perdata pada unit usaha BUMDesa.

Penelitian dengan judul "Tinjauan Yuridis Terhadap Konstruksi Hukum Badan Usaha Milik Desa (BUMDesa) di Kabupaten Banyumas" bertujuan untuk menganalisis konstruksi hukum pada Badan Usaha Milik Desa (BUMDesa) dan untuk menganalisis implementasi pembentukan Badan Usaha Milik Desa di Kabupaten Banyumas, memberikan informasi kepada BUMDesa yang akan dibentuk agar tidak terjadi pelanggaran hukum.

Metode penelitian dengan penelitian hukum yuridis normatif dan spesifikasi penelitian bersifat preskripsi. Metode pengumpulan data adalah studi pustaka atau kepustakaan. Metode penyajian data dalam bentuk uraian yang disusun secara 
sistematis dan metode analisis yang digunakan dalam penelitian ini adalah metode analisis normatif kualitatif.

BUMDesa terkonstruksi bahwa BUMDesa merupakan Perusahaan dan Badan Usaha karena memenuhi ciri-ciri perusahaan yaitu, bertujuan mencari laba, terus menerus, memiliki organisasi. BUMDesa merupakan badan hukum publik karena dibentuk melalui Perdes. BUMDesa merupakan badan hukum publik yang berbentuk Perum karena identik dengan ciri-ciri BUMN yang berbentuk PERUM. Pertanggungjawaban BUMDesa dengan Unit Usaha BUMDesa merupakan perusahaan kelompok karena BUMDesa sebagai perusahaan induk memiliki kesatuan ekonomi dengan unit usaha BUMDesa dan terpisah secara yuridis anatara BUMDesa dengan Unit Usaha BUMDesa. Implementasi BUMDesa di Kabupaten Banyumas bahwa penerapan peraturan perundang-undangan tentang BUMDesa di Kabupaten Banyumas sebagian sudah diterapkan yaitu BUMDesa dibentuk melalui peraturan perundangan yaitu Perdes yang tidak terbagi atas saham, dan pembentukan badan hukum perdata pada unit usaha BUMDesa belum diterapkan dalam jumlah yang banyak.

Kesimpulan, Konstruksi BUMDesa berbentuk Badan Hukum Publik berjenis Perumdes, dengan bentuk pertanggungjawaban dengan unit usaha BUMDesa berbentuk perusahaan kelompok. Implementasi BUMDesa di Kabupaten Banyumas sebagian sudah terlaksana sesuai dengan peraturan perundang-undangan yang berlaku.

Kata Kunci: Konstruksi Hukum, BUMDesa Kabupaten Banyumas.

\section{A. Pendahuluan}

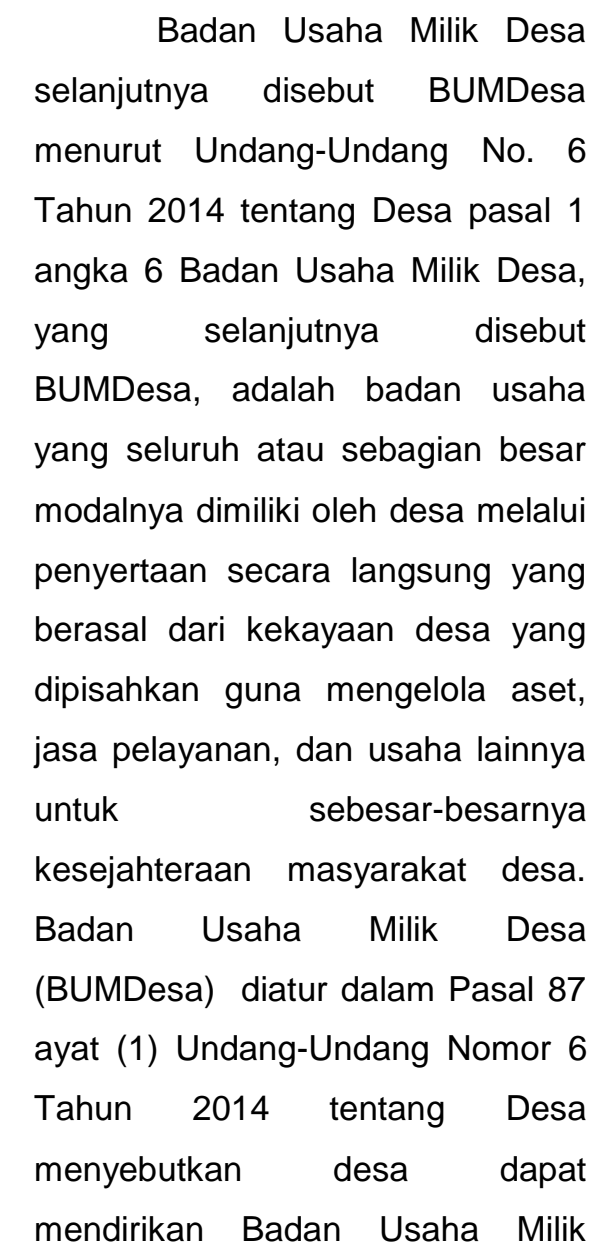

Desa yang disebut BUMDesa, namun tidak menyebutkan secara khusus bentuk dari badan hukum tersebut. Peraturan Menteri Dalam Negeri Nomor 39 Tahun 2010 Tentang Badan Usaha Milik DesaBab II tentang Pembentukan, pasal 2 ayat (2) menyebutkan menjelaskan detail substansi yang harus diatur dalam Peraturan Daerah Kabupaten/Kota tersebut sekurang-kurangnya memuat bentuk organisasi, Peraturan Daerah Kabupaten Banyumas Nomor 6 Tahun 2016 tantang Badan Usaha Milik Desa pasal 6 ayat (2) menyebutkan dalam hal kegiatan usaha telah berjalan dan berkembang dengan baik BUMDesa dapat membentuk unit usaha yang berbadan hukum sesuai dengan ketentuan peraturan perundang-undangan. Peraturan ini 
1351 Jurnal Idea Hukum

Vol. 5 No. 1 Maret 2019

Magister Hukum Fakultas Hukum Universitas Jenderal Soedirman

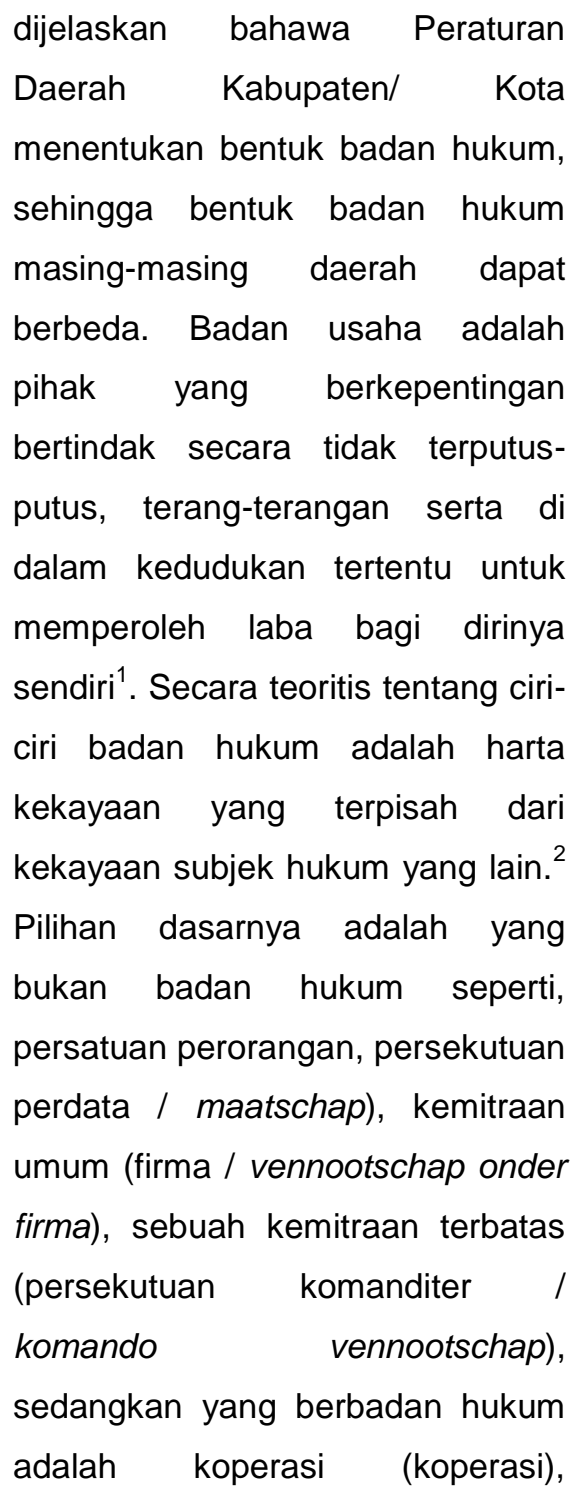

${ }^{1}$ Zaeni Asyhadie, 2012. Hukum Bisnis "Prinsip dan Pelaksanaannya di Indonesia, Rajawali Pers, Jakarta.Hal. 33.

${ }^{2}$ Jimly Asshiddiqie, dalam buku "Perkembangan dan Konsolidasi Lembaga Negara Pasca Reformasi" - Terbitan Mahkamah Konstitusi, Fungsi Dewan KomisarisBumn(berdasarkan UU BUMN dan UU PT)Disampaikan dalamRakor Dewan Pengawas BLUTahun 2012 dan diselenggarakan

DirektoratJenderalPerbendaharaan

Kementerian

KeuanganJakarta,27November2012,http:// dewas.ub.ac.id/wpcontent/uploads/sosialis asidiktimenkeu/Presentasi\%20Fungsi\%20 Dekom\%20BUMN261112.pdf yayasan, atau korporasi ( perseroan terbatas)"3. Badan hukum sendiri terdiri atas badan hukum privat dan badan hukum publik, ciri-ciri badan hukum privat adalah badan hukum yang didirikan atas pernyataan kehendak dari orang perorangan ${ }^{4}$, Ciri-ciri badan hukum publik adalah badan hukum yang didirikan oleh pemerintah dengan peraturan tertentu yang bertujuan untuk kepentingan umum. $^{5}$

Berdasarkan data pada Kementerian Desa PDTT mencatat, saat ini dari 74.957 (tujuh puluh empat ribu sembilan ratus lima puluh tujuh) Desa, Indonesia telah memiliki sebanyak 32.249 (tiga puluh dua ribu duaratus empat puluh Sembilan) Badan Usaha Milik Desa (BUMDesa) ${ }^{6}$. Desa yang berada di Jawa Tengah memiliki 7809 (tujuh ribu delapan ratus sembilan) ${ }^{7}$.Berdasarkan data Dispermadesdukcapil Jawa

${ }^{3}$ Fani A. Siregar, Juni 2012.Master Thesis: Bisnis Organisasi Hukum Reformasi Di Indonesia, Program Magister: Hukum Bisnis Internasional. Hal. 25.

${ }^{4}$ Chaidir Ali, 1999. Badan Hukum. Alumni, Bandung, Hal. 63.

${ }^{5}$ Chidir Ali, Ibid., Hal. 60.

${ }^{6}$ Kemendesa, diakses 14 Agustus 2018, Daftar Badan Usaha Milik Desa(BUMDesa),

http://datin.kemendesa.go.id/simpora/rep_ bumdessmry.php

${ }^{7}$ Ibid.http://datin.kemendesa.go.id/simpora/r pt_jumdesa_nassmry.php?start=7 
Tengah, pada tahun 2017 terdapat 1993 (seribu Sembilan ratus Sembilan puluh tiga) BUMDesa yang telah terbentuk ${ }^{8}$. Berdasarkan hasil penelitian pada Dinas Sosial dan Pemberdayaan Masyarakat dan Desa (DINSOSPERMASDES) Kabupaten Banyumas, diperoleh data berdasarkan data penilaian strata Badan Usaha Milik Desa (BUMDesa) tanggal 11 Maret 2018 diperoleh data sebagai berikut: BUMDesa Dasar: 133 (seratus tiga puluh tiga), BUMDesa Tumbuh: 40 (empat puluh), BUMDesa Berkembang: 4 (empat) dan, BUMDesa Maju: 0 (nol). BUMDesa dasar, tumbuh, dan berkembang, masing-masing memiliki unit usaha. Data BUMDesa Kabupaten Banyumas pada tanggal 26 Maret 2018 sudah terbentuk di 275 (dua ratus tujuh puluh lima) unit usaha. Sebegitu pentingnya pengaturan tentang BUMDesa yang jelas untuk menjaga kepastian hukum.

Fokus penelitian ini adalah mengkonstruksi hukum BUMDesa pada umumnya, yang ditinjau dari aspek BUMDesa merupakan perusahaan atau tidak, bentuk badan hukum pada BUMDesa,

${ }^{8}$ Dispermadesdukcapil Jawa Tengah,diakses 14 Agustus 2018, Open Data Badan Usaha Milik Desa , http://dispermadesdukcapil.jatengprov.go.i d/e-ppid/index.php/data/kategori/?id=10 jenis badan hukum pada BUMDesa, dan bentuk pertanggungjawaban BUMDesa dengan unit usaha BUMDesa. Fokos penelitian yang kedua adalah penerapan BUMDesa di Kabupaten Banyumas diterpakan sudah sesuai dengan peraturan perundang-undangan atau tidak dan kriteria BUMDesa yang berpotensi untuk dapat membentuk badan hukum perdata, dan jenis badan hukum perdata pada unit usaha BUMDesa yang dapat dibentuk di Kabupaten Banyumas. Konstruksi hukum yang digunakan adalah menurut:Bambang Sutiyoso ${ }^{9}$ dalam bukunya, "Metode analogi berarti memperluas peraturan perundang-undangan yang terlalu sempit ruang lingkupnya, kemudian diterapkan terhadap peristiwa yang serupa, sejenis atau mirip dengan yang diatur dalam undang-undang". Analogi ini merupakan metode penemuan hukum dimana hakim mencari esensi yang lebih umum dari sebuah peristiwa hukum atau perbuatan hukum baik yang telah diatur oleh undang-undang maupun yang belum ada peraturannya. Implementasi Hukum menurut teori yang digunakan adalahPenafsiran

9 Bambang Sutiyoso, 2015, Metode Penemuan Hukum (Upaya Meweujudkan Hukum yang Pasti dan Berkeadilan), UII Press, Yogyakarta, Hal. 133. 
1353 Jurnal Idea Hukum

Vol. 5 No. 1 Maret 2019

Magister Hukum Fakultas Hukum Universitas Jenderal Soedirman

Sistematis ${ }^{10}$ Penafsiran sistematis, ialah suatu penafsiran yang menghubungkan pasal yang satu dengan pasal yang lain dalam suatu perundang-undangan yang bersangkutan atau pada perundang-undangan hukum lainnya, atau membaca penjelasan suatu perundang-undangan, sehingga kita mengerti apa yang dimaksud.

Badan Hukum, menurut jenisnya badan hukum digolongkan dalam dua jenis yaitu: (1) badan hukum publik dan (2) badan hukum perdata. ${ }^{11}$ Ciri khas antara badan hukum publik dan badan hukum private bertitik tolak pada bagaimana cara pendirian badan hukum tersebut seperti yang digariskan pada pasal 1653 KUHPerdata yaitu Badan Hukum Publik adalah badan yang dibentuk melalui peraturan perundangan.

Perusahaan memiliki ciriciri tertentu yaitu: ${ }^{12}$ Untuk dapat disebut perusahaan maka organisasi itu harus bertujuan mencari laba. Profit motive. Jenis perusahaan salah satu bentuknya adalah Perusahaan Kelompok

${ }^{10}$ Enju Juanda. Konstruksi Hukum Dan Metode Interpretasi Hukum, Universitas Galuh. Volume 4 No. 2 September 2016. Hal. 162

${ }^{11}$ Chidir Ali, Ibid., Hal. 57.

12 Wasis.1997. Pengantar Ekonomi Perusahaan.PT Alumni. Bandung.Hal. 6 adalah Menurut Emmy Pangaribuan, ${ }^{13} \quad$ Perusahaan Kelompok adalah suatu gabungan atau susunan dari perusahaanperusahaan yang secara yuridis mandiri, yang terkait satu dengan yang lain, sehingga membentuk satu kesatuan ekonomi yang tunduk pada satu perusahaan induk sebagai pimpinan sentral, atau Perusahaan Kelompok adalah dalam bentuk jamak secara yuridis dengan kesatuan ekonomi.

Peraturan Pemerintah

Republik Indonesia Nomor 47 Tahun 2015 Tentang Perubahan Atas Peraturan Pemerintah Nomor 43 Tahun 2014 Tentang Peraturan Pelaksanaan Undang-Undang Nomor 6 Tahun 2014 Tentang Desa, Pasal 1 angka 7 menyebutkan Badan Usaha Milik Desa, selanjutnya disebut BUM Desa, adalah badan usaha yang seluruh atau sebagian besar modalnya dimiliki oleh Desa melalui penyertaan secara langsung yang berasal dari kekayaan Desa yang dipisahkan guna mengelola aset, jasa pelayanan, dan usaha lainnya untuk sebesar-besarnya kesejahteraan masyarakat Desa. Pembentukan unit usaha BUMDesa

\footnotetext{
${ }^{13}$ Emmy Pangaribuan Simanjuntak, 1996, Perusahaan Kelompok (Group Company/Concern). Seksi Hukum Dagang Fakultas Hukum UGM: Yogyakarta, Hal.
} 
sesuai dengan pasal 8 menyebutkan, BUMDesa dapat membentuk unit usaha meliputi: (1) Perseroan Terbatas sebagai persekutuan modal, dibentuk berdasarkan perjanjian, dan melakukan kegiatan usaha dengan modal yang sebagian besar dimiliki oleh BUM Desa, sesuai dengan peraturan perundang-undangan tentang Perseroan Terbatas; (2) Lembaga Keuangan Mikro dengan andil BUM Desa sebesar 60 (enam puluh) persen, sesuai dengan peraturan perundang-undangan tentang lembaga keuangan mikro.

Peraturan

Daerah

Kabupaten Banyumas Nomor 6 Tahun 2016 tentang Badan Usaha Milik Desa, pasal 6 ayat (2) menyebutkan dalam hal kegiatan usaha telah berjalan dengan baik BUMDesa dapat membentuk Unit Usaha yang berbadan hukum sesuai dengan ketentuan peraturan perundang-undangan. Pasal 14 ayat (1) menyebutkan Kekayaan BUMDesa merupakan kekayaan Desa yang dipisahkan dan tidak terbagi atas saham. Berdasarkan hasil penelitian pada Dinas Sosial dan Pemberdayaan Masyarakat dan Desa (DINSOSPERMASDES) Kabupaten Banyumas, diperoleh data berdasarkan data penilaian strata Badan Usaha Milik Desa (BUMDesa) tanggal 11 Maret 2018 diperoleh data sebagai berikut: BUMDesa Dasar: 133 (seratus tiga puluh tiga), BUMDesa Tumbuh: 40 (empat puluh), BUMDesa Berkembang: 4 (empat) dan, BUMDesa Maju: 0 (nol). BUMDesa dasar, tumbuh, dan berkembang, masing-masing memiliki unit usaha.

Data BUMDesa Kabupaten Banyumas pada tanggal 26 Maret 2018 sudah terbentuk di 275 (dua ratus tujuh puluh lima) unit usaha.

BUMDesa yang didirikan di Kabupaten Banyumas telah dilaksanakan Sosialisasi sejak tahun 2016, terbukti adanya Pedoman Pendirian dan Pengelolaan Badan Usaha Milik Desa (BUMDesa) Provinsi Jawa Tengah yang dilakukan oleh Pemerintah Provinsi Jawa Tengah Badan Pemberdayaan Masyarakat Desa, dan ditindaklanjuti oleh Dinsospermasdes Kabupaten Banyumas dengan memberikan penilaian secara periodik kepada BUMDesa yang dibentuk di Kabupaten Banyumas sebagai bentuk kontroling terhadap pemggunaan dana desa.

\section{B. Perumusan Masalah}

1. Bagaimanakah konstruksi hukum pada Badan Usaha Milik Desa (BUMDesa)?

2. Bagaimanakah implementasi pembentukan Badan Usaha 
1355 Jurnal Idea Hukum

Vol. 5 No. 1 Maret 2019

Magister Hukum Fakultas Hukum Universitas Jenderal Soedirman

Milik Desa di Kabupaten

Banyumas?

\section{Mtode Penelitian}

Metode pendekatan yuridis normatif juga dikenal dengan nama penelitian hukum atau legal research $^{14}$ atau doktrinal ${ }^{15}$. Menurut Peter Mahmud Marzuki adalah suatu proses untuk menemukan aturan hukum, prinsip-prinsip hukum. ${ }^{16}$ Konstruksi sebagai instrumen pedoman perilaku dengan fungsi utamanya mengatur perilaku manusia. ${ }^{17}$ Spesifikasi penelitian ini adalah preskripsi, preskripsi merupakan pemecahan atas isu hukum yang diajukan ${ }^{18}$, preskrispsi sendiri secara etimologi berarti apa yang seharusnya $^{19}$.

\footnotetext{
14 Ronny Hanitijo Soemitro, 1982. Metodologi Penelitian, Ghalia Indonesia, Jakarta. Hal. 10.

${ }^{15}$ Amiruddin dan Zainal Asikin, 2013.Pengantar Metode Penelitian Hukum (Cetakan Ketujuh), Rajawali Press, Jakarta. Hal. 118.

${ }^{16}$ Titon Slamet Kurnia dkk, 2013. Pendidikan Hukum, IImu Hukum dan Penelitian Hukum Di Indonesia: Sebuah Reorientasi, Pustaka Pelajar, Yogyakarta. Hal. 129.

17 Adjie Samekto, 2012. IImu Hukum Dalam Perkembangan Pemikiran Menuju Post-Modernisme, Indepth Publishing, Bandar Lampung.Hal. 2.

${ }^{18}$ Tim Redaksi Tesaurus, 2008. Kamus Besar Bahasa Indonesia, Pusat Bahasa Departemen Pendidikan Nasional. Hal. 1213.

19 Titon, Op.Cit., Hal. 129.
}

Legal research merupakan penelitian yang menggunakan bahan hukum primer dan bahan hukum sekunder. ${ }^{20}$ Metode pengumpulan bahan hukum yang digunakan dalam penelitian ini adalah studi pustaka atau kepustakaan. $^{21}$ Metode analisis yang digunakan dalam penelitian ini adalah metode analisis normatif kualitatif yakni analisis yang menekankan pada proses penyimpulan deduktif dan induktif $^{22}$. Penelitian hukum normatif (normative law research) menggunakan studi kasus hukum normatif mengkaji peraturan perundang-

undangan. ${ }^{23}$ Penggunaan metode analisis data kualitatif ini menelaah sistematika peraturan perundang-undangan dengan melakukan konstruksi hukum kedalam kategori-kategori atas dasar pengertian-pengertian dasar dari sistem hukum tersebut. $^{24}$

${ }^{20}$ Titon., Ibid, Hal. 141.

$21 \quad$ M. Syamsyudin, 2007. Operasionalisasi Penelitian Hukum, Rajawali Press, Jakarta. Hal. 101-102.

22 Ronny Hantijo Soemitro, Op.Cit.,Hal. 133.

${ }^{23}$ Abdulkadir Muhammad, 2004, Hukum dan Penelitian Hukum, Cet. 1, PT. Citra Aditya Bakti, Bandung, Hal. 52

${ }^{24}$ Soerjono Soekanto dan Sri Pamuji,2011. Penelitian Hukum Normatif,Rajawali Press, Jakarta . Hal. 255. 
D. Hasil Penelitian dan Pembahasan

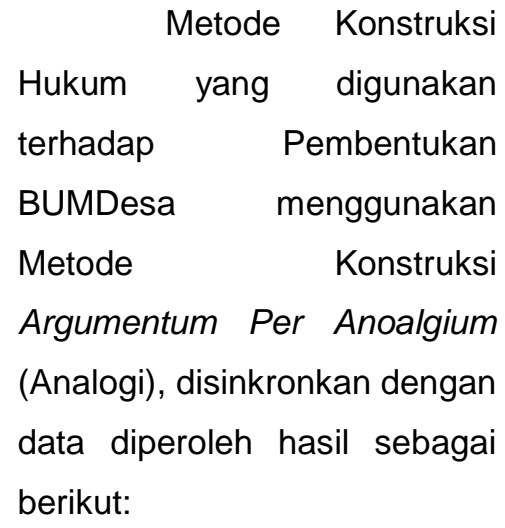

1) BUMDesa merupakan Perusahaan dan Badan Usaha

Badan Usaha

Milik Desa (BUMDesa)

memiliki ciri sesuai dengan (Pasal 87 UU No.

6 Tahun 2014 tentang

Desa) yaitu menjalankan usaha di bidang ekonomi dan/atau pelayanan umum sesuai dengan ketentuan peraturan perundang-undangan, bersesuaian dengan ciri perusahaan pada kegiatan usaha dibidang ekonomi yaitu kegiatan secara terus menerus memiliki kedudukan tertentu untuk memperoleh keuntungan.

Ciri BUMDesa sebagai

Perusahaan

sebagaimana disebutkan pada (Pasal 132 ayat 4 J.o. Pasal 133 PP No. 47
Tahun 2015 Tentang Perubahan Atas PP No. 43 Tahun 2014 Tentang Peraturan Pelaksanaan UU No. 6 Tahun 2014 Tentang Desa) yaitu Organisasi Pengelola BUMDesa memiliki Penasihat dan Pelaksana Operasional, bersesuaian dengan ciri perusahaan memiliki Organ. Ciri BUMDesa memiliki kekayaan yang terpisahkan dengan disebutkan pada (Pasal 135 PP No. 47 Tahun 2015 Tentang Perubahan Atas PP No. 43 Tahun 2014 Tentang Peraturan Pelaksanaan UU No. 6 Tahun 2014 Tentang Desa) tentang Modal dan Kekayaan BUMDesa, bersesuaian dengan ciri perusahaan yang memiliki harta kekayaan secara terpisah, BUMUDesa merupakan Badan Usaha yang melakukan kegiatan usaha. Tersimpulkan bahwa BUMDesa merupakan Perusahaan dan Badan Usaha.

2) BUMDesa merupakan Badan Hukum Publik 
1357 Jurnal Idea Hukum

Vol. 5 No. 1 Maret 2019

Magister Hukum Fakultas Hukum Universitas Jenderal Soedirman

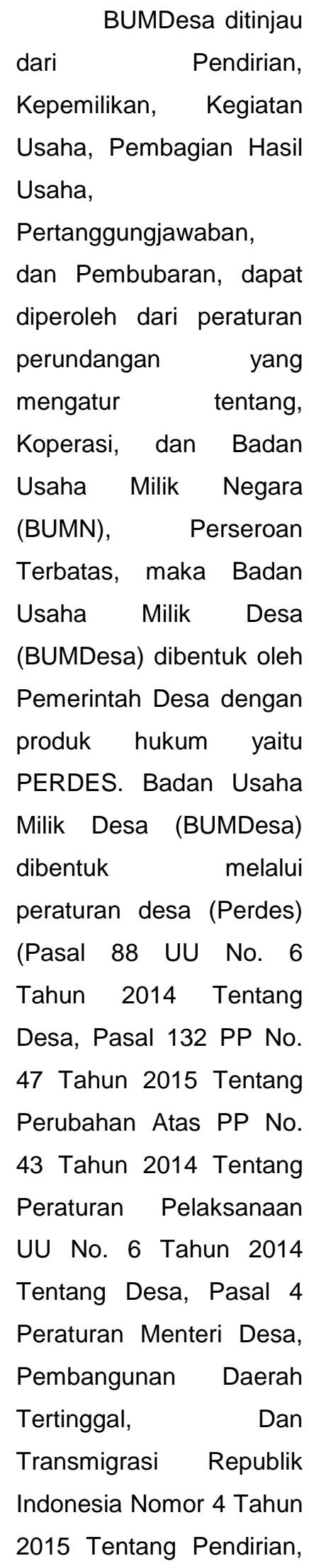

Pengurusan Dan

Pengelolaan, Dan

Pembubaran Badan

Usaha Milik Desa, dan

Pasal 5 Perda Kabupaten

Banyumas No. 6 Tahun

2016 tentang Badan

Usaha Milik Desa) dan

melakukan kegiatan

secara terus menerus

untuk memproduksi atau

menjual barang dan/atau

jasa tertentu, merupakan

Perusahaan yang

berbentuk Badan Hukum

Publik, untuk

mendayagunakan segala

potensi ekonomi,

kelembagaan

perekonomian, serta

potensi sumber daya

alam dan sumber daya

manusia dalam rangka

meningkatkan

kesejahteraan

masyarakat Desa.

Tersimpulkan bahwa

BUMDesa merupakan

Badan Hukum Publik.

3) BUMDesa merupakan

Badan Hukum Publik

yang berbentuk Perum

Penelitian Amelia

Sri Kusuma ${ }^{25}$ Dewi Dosen

${ }^{25}$ A. Sri Kusuma Dewi, Oktober 2010, Korespondensi: Fakultas Hukum 
Fakultas

Hukum

Universitas

Brawijaya

tentang Alternatif Bentuk

Badan Hukum yang Tepat

dalam Pendirian Badan

Usaha Milik Desa

(BUMDes) sebagai Upaya

Meningkatkan

Pendapatan

Asli Desa

(PADes).

Penelitian

Amelia Sri Kusuma Dewi mengemukakan Alternatif

Bentuk Badan Hukum

yang Tepat dalam

Pendirian BUMDes

Disyaratkan dalam pasal

78 ayat (3) Peraturan

Pemerintah Nomor 72

Tahun 2005 tentang

Desa, bahwa Bentuk

Badan Usaha Milik Desa

harus berbadan hukum,

maka bentuk badan

hukum yang tepat dalam

mendirikan BUMDes

meliputi: a) Perusahaan

Umum Desa (Perumdes),

atau B) Perseroan

Terbatas (Perseroan

Desa). Penulis setuju

terhadap dengan bentuk

Perumdes dengan alasan

sinkronisasi peraturan

Universitas Brawijaya, JI MT Haryono

169Malang,

Email:

amelia fhub@yahoo.co.id., Pamator,

Volume 3, Nomor 2, Hal. 118 perundang-undangan

yang mengatur tentang

Konstruksi badan hukum dengan konstruksi Badan Usaha

Milik Desa (BUMDesa) maka dapat diperoleh data sebagai berikut:

\begin{tabular}{|c|c|c|c|c|}
\hline $\begin{array}{l}\text { INDIKATO } \\
\mathrm{R}\end{array}$ & $\begin{array}{l}\text { KOPER } \\
\text { ASI }\end{array}$ & $\begin{array}{l}\text { BUMN } \\
\text {-PT (Persero) } \\
\text {-Perum }\end{array}$ & $\begin{array}{l}\text { PERS } \\
\text { EROA } \\
N \\
\text { TERB } \\
\text { ATAS }\end{array}$ & BUMDesa \\
\hline Pendirian & $\begin{array}{l}\text { Pejabat } \\
\text { Notaris }\end{array}$ & $\begin{array}{l}\text {-PT (Persero) } \\
\text { Pendirian } \\
\text { Persero } \\
\text { diusulkan oleh } \\
\text { Menteri kepada } \\
\text { Presiden } \\
\text {-Perum } \\
\text { Perum } \\
\text { memperoleh } \\
\text { status badan } \\
\text { hukum sejak } \\
\text { diundangkann } \\
\text { ya Peraturan } \\
\text { Pemerintah } \\
\text { tentang } \\
\text { pendiriannya }\end{array}$ & $\begin{array}{l}\text { Pejab } \\
\text { at } \\
\text { Notari } \\
\mathrm{s}\end{array}$ & $\begin{array}{l}\text { Peraturan } \\
\text { Pemerinta } \\
\text { h Desa }\end{array}$ \\
\hline $\begin{array}{l}\text { Kepemilika } \\
\text { n, }\end{array}$ & Private & $\begin{array}{l}\text {-Persero } \\
\text { Terbagi atas } \\
\text { saham, minimal } \\
51 \% \text { milik } \\
\text { Negara } \\
\text {-Perum } \\
\text { yang seluruh } \\
\text { modalnya } \\
\text { dimiliki negara } \\
\text { dan tidak } \\
\text { terbagi atas } \\
\text { saham }\end{array}$ & $\begin{array}{l}\text { Privat } \\
\mathrm{e}\end{array}$ & $\begin{array}{l}\text { Modal } \\
\text { Desa } \\
\text { secara } \\
\text { Dominan } \\
\text { tidak } \\
\text { terbagi } \\
\text { atas } \\
\text { saham }\end{array}$ \\
\hline $\begin{array}{l}\text { Kegiatan } \\
\text { Usaha }\end{array}$ & $\begin{array}{l}\text { Keseja } \\
\text { hteraan } \\
\text { Anggot } \\
\text { a }\end{array}$ & $\begin{array}{l}\text {-Persero } \\
\text { mengejar } \\
\text { keuntungan } \\
\text { guna } \\
\text { meningkatkan } \\
\text { nilai } \\
\text { perusahaan } \\
\text {-Perum, } \\
\text { bertujuan } \\
\text { untuk } \\
\text { kemanfaatan } \\
\text { umum }\end{array}$ & $\begin{array}{l}\text { Profit } \\
\text { Orient } \\
\text { ed }\end{array}$ & $\begin{array}{l}\text { Kesejahte } \\
\text { raan } \\
\text { Masyarak } \\
\text { at Desa }\end{array}$ \\
\hline
\end{tabular}


1359 Jurnal Idea Hukum

Vol. 5 No. 1 Maret 2019

Magister Hukum Fakultas Hukum Universitas Jenderal Soedirman

\begin{tabular}{|c|c|c|c|c|}
\hline $\begin{array}{l}\text { Pembagian } \\
\text { Hasil } \\
\text { Usaha }\end{array}$ & $\begin{array}{l}\text { Sebata } \\
\text { s pada } \\
\text { Anggot } \\
\text { anya }\end{array}$ & $\begin{array}{l}\text {-Persero } \\
\text { Sesuai } \\
\text { Pemegang } \\
\text { Saham } \\
\text {-Perum } \\
\text { Penggunaan } \\
\text { laba bersih } \\
\text { Perum oleh } \\
\text { ditetapkan } \\
\text { Menteri }\end{array}$ & $\begin{array}{l}\text { Sesu } \\
\text { ai } \\
\text { Peme } \\
\text { gang } \\
\text { Saha } \\
\mathrm{m}\end{array}$ & $\begin{array}{l}\text { Bagi } \\
\text { Hasil, } \\
\text { kegotongr } \\
\text { oyongan, } \\
\text { kesejahter } \\
\text { aan } \\
\text { masyarak } \\
\text { at Desa }\end{array}$ \\
\hline $\begin{array}{l}\text { Pertanggu } \\
\text { ngjawaban }\end{array}$ & $\begin{array}{l}\text { Intern } \\
\text { dan } \\
\text { ektern }\end{array}$ & $\begin{array}{l}\text { Intern dan } \\
\text { ektern }\end{array}$ & $\begin{array}{l}\text { Intern } \\
\text { dan } \\
\text { ekster } \\
\mathrm{n}\end{array}$ & $\begin{array}{l}\text { Intern dan } \\
\text { ekstern }\end{array}$ \\
\hline $\begin{array}{l}\text { Pembuba } \\
\text { ran, }\end{array}$ & $\begin{array}{l}\text { Melalui } \\
\text { musya } \\
\text { warah } \\
\text { anggot } \\
\text { a }\end{array}$ & $\begin{array}{l}\text {-Persero } \\
\text { Sesuai } \\
\text { dengan } \\
\text { Peraturan } \\
\text { Perundangan } \\
\text { tentang } \\
\text { Persero } \\
\text {-Perum } \\
\text { Menggunaka } \\
\text { n peraturan } \\
\text { perundangan } \\
\text { dan } \\
\text { persetujuan } \\
\text { Menteri }\end{array}$ & $\begin{array}{l}\text { Sesu } \\
\text { ai } \\
\text { deng } \\
\text { an } \\
\text { perat } \\
\text { uran } \\
\text { peru } \\
\text { ndan } \\
\text { gan } \\
\text { dan } \\
\text { ADA } \\
\text { RT } \\
\text { Pers } \\
\text { eroa } \\
n\end{array}$ & $\begin{array}{l}\text { Sesuai } \\
\text { dengan } \\
\text { ADART } \\
\text { yang } \\
\text { tertuang } \\
\text { pada } \\
\text { PERDES }\end{array}$ \\
\hline
\end{tabular}

Berdasarkan

pembahasan teori secara sistematis dengan kategori-kategori tertentu sehingga BUMDesa memenuhi ciri-ciri seperti BUMN yang berbentuk Perum, sehingga dapat disimpulkan bahwa BUMDesa merupakan Badan Hukum Publik yang berbentuk Perum.

\section{4) Pertanggungjawaban BUMDesa dengan Unit}

Usaha merupakan

Perusahaan Kelompok

Berdasarkan teori

tentang Perusahaan

Kelompok dan

disinkronkan dengan ciri-

ciri Pertanggungjawaban

Unit Usaha dengan

BUMDesa sebagai induk maka konstruksi Hukum Badan Usaha Milik Desa (BUMDesa) yang merupakan Badan Hukum Publik, didalamnya terdapat unit-unit usaha yang tidak sejenis, dapat berupa unit usaha pengelolaan sampah, unit usaha Lembaga Keuangan Mikro, Unit Usaha Koperasi, unit usaha Pengelolaan Air minum, unit usaha jual beli hasil usaha, dan unit usaha lainnya, yang didalamnya memiliki struktur organisasi tersendiri, diamana unit usaha yang berebntuk badan hukum bertanggungjawab terbatas pada kegiatan usaha yang dilakukan dengan pertanggungjawaban kepada induk Badan Usaha yaitu Badan Usaha 
Milik Desa (BUMDesa)

(Pasal 137 (1) PP No. 47

Tahun 2015 Tentang

Perubahan Atas PP

Nomor 43 Tahun 2014

Tentang Peraturan

Pelaksanaan Undang-

Undang Nomor 6 Tahun

2014 Tentang Desa)

BUMDesa dapat

membentuk unit-unit

usaha, artinya bentuk

pertanggungjawaban

antara BUMDesa dengan

unit usaha memiliki

kesatuan Ekonomi dan

terpisah secara Yuridis

(Pasal 7, Pasal 8)

Peraturan Menteri Desa,

Pembangunan Daerah

Tertinggal, Dan

Transmigrasi Republik

Indonesia Nomor 4 Tahun

2015 Tentang Pendirian,

Pengurusan Dan

Pengelolaan, Dan

Pembubaran Badan

Usaha Milik Desa)

J.o.modal yang sebagian

besar dimiliki oleh BUM

Desa sehingga BUMDesa

sebagai perusahaan

induk sebagai pusat

kontrol terhadap unit-unit

usaha tersebut.

BUMDesa dapat terdiri

dari unit-unit usaha yang berbadan hukum, dan

Unit Usaha yang tidak

berebentuk badan hukum,

pertanggungjawaban

langsung pada Badan

Usaha Milik Desa

(BUMDesa) sebagai

organisasi induk, maka

berdasarkan hal tersebut,

Konstruksi Hukum Badan

Usaha Milik Desa

bersesuaian dengan

Perusahaan Kelompok.

Tersimpulkan bahwa

BUMDesa dengan Unit

Usaha merupakan

Perusahaan Kelompok.

5) Implementasi BUMDesa

di

Kabupaten

\section{Banyumas}

Implementasi

BUMDesa di kabupaten

Banyumas, sebagian

besar sudah di terapkan

pada 23 kecamatan dari

27 kecamatan yang 4

Kecamatan diantaranya

masing-masing

perwilayahnya berbentuk

kelurahan sehingga tidak

membentuk BUMDesa.

Sehingga Implementasi

Badan Usaha Milik Desa

(BUMDesa) di Kabupaten

Banyumas sudah

terlaksana.Berdasarkan 
1361 Jurnal Idea Hukum

Vol. 5 No. 1 Maret 2019

Magister Hukum Fakultas Hukum Universitas Jenderal Soedirman

hasil penelitian diperoleh data jenis usaha dan kelompok usaha. Jenis usaha yang dibentuk di Kabupaten Banyumas terdiri dari jasa keuangan sejumlah: 169 unit usaha, jasa non keuangan 203 unit usaha, persewaan 143 unit usaha, perdagangan 226 unit usaha, wisata 160 unit usaha, pertanian 189 unit usaha, peternakan 178 unit usaha, perikanan 182 unit usaha, dan kerajinan 185 unit usaha. Kelompok usaha BUMDesa di Kabupaten Banyumas terbentuk bisnis sosial sejumlah: 81 kelompok usaha, bisnis keuangan 67 kelompok usaha, bisnis persewaan 18 kelompok usaha, jasa perantara 32 kelompok usaha, bisnis produksi 86 kelompok usaha, dan usaha bersama 64 kelompok usaha. diperoleh data berdasarkan data penilaian strata Badan Usaha Milik Desa (BUMDesa) tanggal 11 Maret 2018 diperoleh data sebagai berikut:
BUMDesa Dasar: 133 (seratus tiga puluh tiga), BUMDesa Tumbuh: 40 (empat puluh), BUMDesa Berkembang: 4 (empat) dan, BUMDesa Maju: 0 (nol). BUMDesa dasar, tumbuh, dan berkembang, masingmasing memiliki unit usaha. Data BUMDesa Kabupaten Banyumas pada tanggal 26 Maret 2018 sudah terbentuk di 275 (dua ratus tujuh puluh lima) unit usaha.

\section{Berdasarkan}

peraturan perundangan yang disinkronkan dengan data yang diperoleh, maka dapat ditarik sebuah kesimpulan bahwa pembentukan unit usaha BUMDesa di Kabupaten Banyumas yang berpotensi menjadi badan hukum perdata adalah baru sejumlah 4 (empat) BUMDesa, hasil penilain tersebut mencerminkan bahwa BUMDesa di Kabupaten Banyumas masih sangat kecil untuk berkembang dengan baik, oleh karenanya perlu dikakukan sosialisasi dan 
pelatihan lebih lanjut agar tujuan pembentukan

BUMDesa di Kabupaten

Banyumas dapat berkembang dengan baik. Pembentukan

BUMDesa yang tidak terbagi atas saham, mempertegas bahwa

BUMDesa bukan berebentuk perseroan terbatas, melainkan bentuk lain yaitu bentuk badan hukum yang dibentuk melalui peraturan perundangan dalam hal ini Perdes, yang identik dengan bentuk badan hukum publik yaitu Perum, terkhusus yaitu Perumdes. Berbeda dengan Pembentukan unit usaha BUMDesa yang berbadan hukum perdata baik perseroan terbatas atau koperasi, memiliki syarat tertentu yaitu apabila BUMDesa sudah berkembang dengan baik, BUMDesa dapat membentuk unit usaha yang berbadan hukum perdata, dengan demikian potensi pembentukan unit usaha BUMDesa yang dapat membentuk Badan Hukum Perdata, baru berjumlah 4 (empat) BUMDesa. Sehingga dapat disimpulkan bahwa penerapan peraturan perundang-undangan tentang BUMDesa di Kabupaten Banyumas sebagian sudah diterapkan dan sebagian belum diterapkan dengan baik karena berdasarkan penilaian yang dilakukan oleh Dinsospermasdes BUMDesa yang memiliki nilai berkembang dinilai masih sangat sedikit.

\section{G. Kesimpulan}

1. Konstruksi hukum BUMDesa terkonstruksi bahwa BUMDesa merupakan Perusahaan dan Badan Usaha karena memenuhi ciri-ciri perusahaan yaitu, bertujuan mencari laba, terus menerus, memiliki organisasi, dan berkedudukan. BUMDesa merupakan badan hukum publik karena dibentuk melalui peraturan perundangundangan yaitu Perdes. BUMDesa merupakan badan hukum publik yang berbentuk Perum karena konstruksi hukum yang ditinjau dari pendirian, kepemilikan, 
1363 Jurnal Idea Hukum

Vol. 5 No. 1 Maret 2019

Magister Hukum Fakultas Hukum Universitas Jenderal Soedirman

kegiatan usaha, pembagian hasil usaha, pertanggungjawaban, dan pembubaran identik dengan ciri-ciri BUMN yang berbentuk PERUM. Pertanggungjawaban BUMDesa dengan Unit Usaha BUMDesa merupakan perusahaan kelompok karena BUMDesa sebagai perusahaan induk memiliki kesatuan ekonomi dengan unit usaha BUMDesa dan terpisah secara yuridis anatara BUMDesa dengan Unit Usaha BUMDesa

2. Implementasi BUMDesa di Kabupaten Banyumas bahwa penerapan peraturan perundang-undangan tentang BUMDesa di Kabupaten Banyumas sebagian sudah diterapkan yaitu BUMDesa dibentuk melalui peraturan perundangan yaitu Perdes yang tidak terbagi atas saham, dan pembentukan badan hukum perdata pada unit usaha BUMDesa belum diterapkan dalam jumlah yang banyak karena berdasarkan penilaian yang dilakukan oleh Dinsospermasdes BUMDesa yang memiliki nilai berkembang dinilai masih sangat sedikit, sehingga pembentukan unit usaha BUMDesa yang berbentuk badan hukum perdata tidak dapat diterapakan bagi BUMDesa yang tidak mencapai nilai BUMDesa berkembang. Badan hukum perdata pada unit usaha BUMDesa yang dapat dibentuk di Kabupaten Banyumas adalah badan hukum perdata yang memiliki ciri-ciri perusahaan yaitu koperasi dan perseroan terbatas.

\section{DAFTAR PUSTAKA}

Ali, Chaidir. 1999. Badan Hukum. Alumni, Bandung

Hukum,

$$
\text { Alumni,Bandung }
$$

Asyhadie, Zaeni. 2012. Hukum Bisnis "Prinsip dan Pelaksanaannya di Indonesia". Rajawali Pers, Jakarta

Asikin, A. d. 2013. Pengantar Metode Penelitian Hukum.Cetakan Ketujuh Rajawali Press,Jakarta

Muhammad,

Abdulkadir. 1995.Pengantar Hukum Perusahaan di Indonesia, PT. Citra Aditya Abadi,Bandung

Soemitro, R. H. 1982. Metodologi Penelitian, . Jakarta: Ghalia Indonesia.

Samekto, Adji. 2012. Ilmu Hukum Dalam Perkembangan Pemikiran Menuju Post-Modernisme. Indepth

Publishing, Bandar Lampung

Samekto, Adji. 2012. Ilmu Hukum Dalam Perkembangan Pemikiran Menuju Post-Modernisme. Indepth

Publishing, Bandar Lampung

Slamet, Titon K. d. 2013. Pendidikan Hukum, IImu Hukum dan Penelitian Hukum Di Indonesia: Sebuah Reorientasi. Pustaka Pelajar, Yogyakarta

Sutiyoso, Bambang. 2015, Metode Penemuan Hukum (Upaya 
Meweujudkan Hukum yang Pasti dan Berkeadilan), UII Press, Yogyakarta

Syamsyudin, M. 2007. Operasionalisasi Penelitian Hukum. Rajawali Press, Jakarta

Wasis.1997. Pengantar Ekonomi Perusahaan.PT Alumni. Bandung.

A. Sri Kusuma Dewi, Oktober 2010, Korespondensi: Fakultas Hukum Universitas Brawijaya, JI MT Haryono 169Malang, Email: amelia fhub@yahoo.co.id., Pamator, Volume 3, Nomor 2, Hal. 118

Anoname, Metode Penelitian Hukum Normatif, FHUNSOED(2014,Desember8).R etrievedfrom:http://fh.unsoed.ac.id /sites/default/files/BAB\%20III\%20 METODE\%20PENELITIAN.doc

Dispermadesdukcapil Jawa Tengah, diakses 14 Agustus 2018, Open Data Badan Usaha Milik Desa , http://dispermadesdukcapil.jateng prov.go.id/e-

$\mathrm{ppid} / \mathrm{index} \cdot \mathrm{php} / \mathrm{data} / \mathrm{kategori} / \mathrm{id}=$ 10

Enju Juanda. Konstruksi Hukum Dan Metode Interpretasi Hukum, Universitas Galuh. Volume 4 No. 2 September 2016. Hal. 162

Emmy Pangaribuan Simanjuntak, 1996, Perusahaan Kelompok (Group Company/Concern). Seksi Hukum Dagang Fakultas Hukum UGM: Yogyakarta, Hal. 1

Fani A. Siregar, Juni 2012.Master Thesis: Bisnis Organisasi Hukum Reformasi Di Indonesia, Program Magister: Hukum Bisnis Internasional. Hal. 25

Jimly Asshiddiqie, dalam buku "Perkembangan dan Konsolidasi Lembaga Negara Pasca Reformasi" - Terbitan Mahkamah Konstitusi, Fungsi Dewan KomisarisBumn(berdasarkan UU BUMN dan UU PT)Disampaikan dalamRakor Dewan Pengawas BLUTahun 2012 dan diselenggarakan di DirektoratJenderalPerbendaharaa n

Kementerian
KeuanganJakarta,27November20 12,http://dewas.ub.ac.id/wpconten t/uploads/sosialisasidiktimenkeu/P resentasi\%20Fungsi\%20Dekom\% 20BUMN261112.pdf

Kemendesa, diakses 14 Agustus 2018, Daftar Badan Usaha Milik Desa(BUMDesa),http://datin.kem endesa.go.id/simpora/rep bumde ssmry.php

Kemendesa, diakses 14 Agustus 2018, Daftar Badan Usaha Milik Desa(BUMDesa),http://datin.kem endesa.go.id/simpora/rep bumde ssmry.php

Tim Redaksi Tesaurus, 2008. Kamus Besar Bahasa Indonesia, Pusat Bahasa Departemen Pendidikan Nasional. 